\title{
RASIO SOLVABILITAS
}

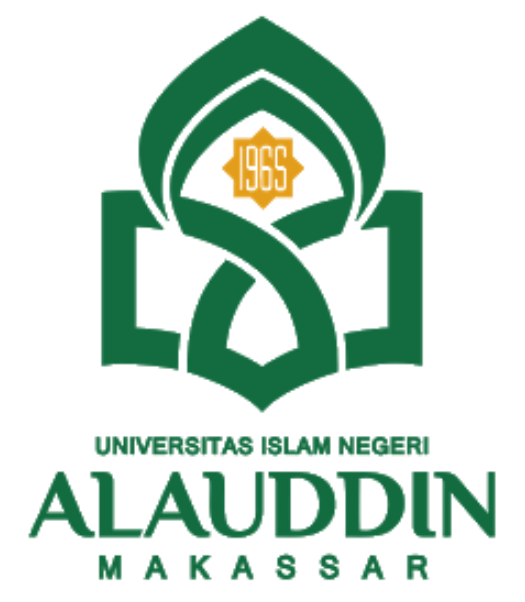

MAKALAH

Dibuat untuk memenuhi tugas presentasi mata kuliah Analisis Laporan Keuangan semester 5 Tahun 2021

\section{Disusun Oleh :}

Rizky Amaliyah Ramdhani Ilham (90500119068)

Novira Putri Arlianti (90500119072)

Muh. Rezky Aditya (90500119080)

\section{Dosen Pengajar :}

Ismawati, S.E., M.Si.

\author{
PERBANKAN SYARIAH \\ FAKULTAS EKONOMI DAN BISNIS ISLAM \\ UIN ALAUDDIN MAKASSAR
}

2021/2022 


\section{KATA PENGANTAR}

Puji syukur Alhamdulillah, penulis panjatkan kehadirat Allah SWT. Yang telah melimpahkan segala rahmat, taufik dan hidayah-Nya sehingga makalah yang kami yang berjudul "Rasio Solvabilitas" ini bisa selesai.

Shalawat dan salam semoga tercurah limpahkan pada junjungan kita Nabi Muhammad SAW. Yang sudah membawa kita dari zaman yang penuh kegelapan menuju zaman yang terang - menderang.

Melalui makalah ini penulis harapkan pembaca bisa memahami dan mengetahui lebih banyak perihal Rasio solvabilitas. Kami sebagai penyusun menyadari bahwa masih banyak terdapat kesalahan serta kekurangan pada pada penulisan makalah ini. Oleh karena itu, kami berharap dan mendapatkan segala bentuk saran serta kritik asal pembaca yang dapat berguna bagi perbaikan serta perkembangan makalah selanjutnya.

Makassar, Oktober 2021

Penyusun 


\section{DAFTAR ISI}

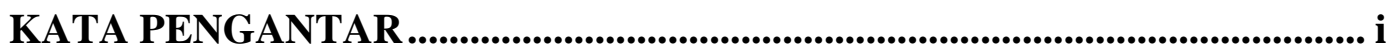

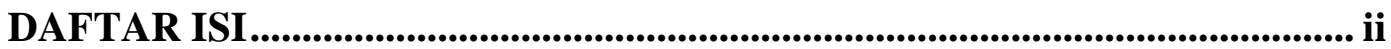

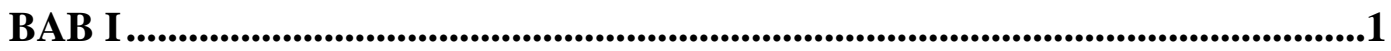

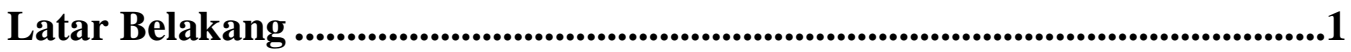

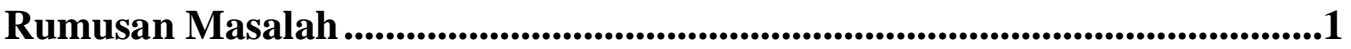

A. Pengertian Rasio Solvabilitas...........................................................

B. Tujuan dan Manfaat Rasio Solvabilitas .................................................4

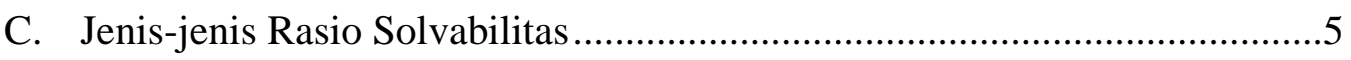

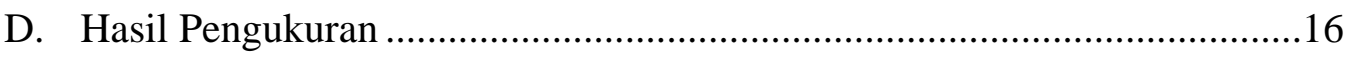

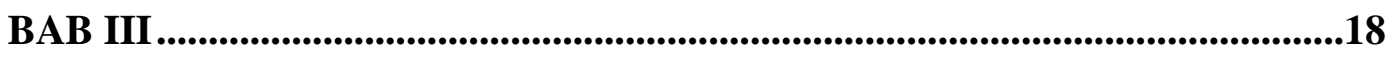

Kesimpulan ........................................................................................................................18

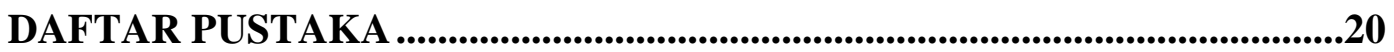




\section{BAB I \\ PENDAHULUAN}

\section{Latar Belakang}

Untuk menjalankan operasinya setiap perusahaan memiliki banyak sekali kebutuhan, terutama yang berkaitan menggunakan dana supaya perusahaan dapat berjalan sebagaimana mestinya. Dana selalu diperlukan buat menutupi semua atau sebagian dari biaya yang dibutuhkan, baik dana jangka pendek maupun jangka panjang. Dana juga diperlukan buat melakukan ekspansi atau perluasan usahaatau investasi baru. Artinya di dalam perusahaan wajib : selalu tersedia dana pada jumlah eksklusif sehingga tersedia di ketika diperlukan. pada hal ini, tugas manajer keuanganlah yang bertugas memenuhi kebutuhan tersebut. Didalam praktiknya untuk menutupi kekurangan kebutuhan dana, perusahaan memiliki beberapa pilihan yaitu, Dana yang dapat digunakan. Pemilihan sumber dana ini tergantung berasal tujuan, syarat-syarat, keuntungan, dan kemampuan perusahaan tentunya. sumbersumber dana secara garis akbar dapat diperoleh dari kapital sendiri dan pinjaman (bank atau forum keuangan lainnya). Perusahaan bisa menentukan dana berasal salah satu asal tersebut atau kombinasi berasal keduanya.

\section{Rumusan Masalah}

1. Bagaimana Pengertian Rasio Solvabilitas ?

2. Bagaimana Tujuan Dan Manfaat Rasio Solvabilitas?

3. Apa saja Jenis-jenis Rasio Solvabilitas ?

4. Bagaimana Hasil Pengukuran? 


\section{BAB II}

\section{PEMBAHASAN}

\section{A. Pengertian Rasio Solvabilitas}

Setiap sumber dana mempunyai kelebihan serta kekurangannya masingmasing. Contohnya penggunaan modal sendiri mempunyai kelebihan, yaitu simpel diperoleh, (persyaratan ringan) serta beban pengembalian yang relatif lama disamping samping itu, dengan memakai modal sendiri, tidak terdapat beban untuk membayar angsuran termasuk bunga serta biaya lainnya. Kebalikannya, kekurangan penggunaan modal sendiri sebagai sumber dana ialah jumlahnya yg relatif terbatas, terutama di saat membutuhkan dana yang relatif besar.

Bila memilih modal pinjaman, kelebihannya adalan jumlahnya yang cukup tidak terbatas serta menambah motivasi manajemen buat bekerja lebih aktif serta kreatif sebab dibebani buat membayar beban kewajibannya. Sekalipun terkadang lebih risiko, untuk investasi tertentu manajemen menggunakan modal pinjaman. Sementara itu, kekurangannya artinya persyaratan untuk memperolehnya relatif sulit. Ialah, untuk memperoleh dana, diharapkan syarat-syarat tertentu yang transparan. Hal inilah yang terkadang membentuk perusahaan sulit buat memenuhinya. Pada samping itu, kelemahannya ialah perusahaan (debitur) dibebani pembayaran angsuran atau cicilan (pokok pinjaman + bunga) serta biaya lainnya mirip porto administrasi, porto provisi, dan komisi.

Oleh karena itu, mengingat penggunaan keliru satu asal dana tersebut mempunyai kelebihan dan kekurangan, perlu disiasati agar bisa saling menunjang. Caranya merupakan menggunakan melakukan kombinasi asal masing-masing jumlah asal dana. Besarnya penggunaan masing-masing asal dana harus dipertimbangkan agar tidak membebani perusahaan, baik jangka pendek maupun jangka panjang. Dengan istilah lain, penggunaan dana yang bersumber berasal pinjaman harus dibatasi. Kombinasi asal penggunaan dana dikenal menggunakan 
nama rasio penggunaan dana pinjaman atau utang atau dikenal menggunakan nama rasio solvabilite atau rasio leverage.

Rasio solvabilitas atau leverage ratio adalah rasio yang dipergunakan untuk mengukur sejauh mana aktiva perusahaan dibiayai menggunakan utang. Ialah berapa besar beban utang yang ditanggung perusahaan dibandingkan dengan aktivanya. Pada arti luas dikatakan bahwa rasio solvabilitas dipengaruhi untuk mengukur kemampuan perusahaan untuk membayar semua kewajibannya, baik jangka pendek juga jangka panjang jika perusahaan dibubarkan (dilikuidasi).

Penggunaan rasio solvabilitas perusahaan memberikan banyak manfaat yang bisa dipetik, baik rasio rendah juga rasio tinggi. Dari Fred Weston rasio solvabilitas beberapa implikasi berikut.

1. Kreditor mengharapkan ekuitas (dana yang disediakan pemilik) menjadi marjin keamanan. Artinya Bila pemilik memilikidana yg kecil menjadi kapital, risiko bisnis terbesar akan ditanggung sang kreditor.

2. Menggunakan pengadaan dana melalui utang, pemilik memperoleh manfaat, berupa tetap dipertahankannya penguasaan atau pengendalian perusahaan.

3. Jika perusahaan mendapat penghasilan lebih berasal dana yang dipinjamkannya dibandingkan dengan bunga yang wajib dibayarnya, pengembalian pada pemilik diperbesar.

Didalam praktiknya, jika dari hasil perhitungan, perusahaan ternyata mempunyai rasio solvabiliteit tinggi, hal ini akan berdampak timbulnya risiko kerugian lebih besar, tetapi juga ada kesempatan mendapat untung juga besar, kebalikannya jika perusahaan mempunyai rasio solvabiliteit rendah tentu mempunyai risiko kerugian lebih kecil juga, terutama pada ketika perekonomian menurun. Dampak ini juga menyebabkan rendahnya tingkat yang akan terjadi pengembalian (return) di saat perekonomian tinggi. 
Oleh sebab itu manajer keuangan dituntut buat mengelola rasio solvabilitas baik sehingga bisa menyeimbangkan pengembalian yang tinggi menggunakan tingkat risiko yang dihadapl. Perlu dicermati pula bahwa besar kecilnya rasio ini sangat tergantung asal pinjaman yang dimiliki perusahaan, pada samping aktiva yang dimilikinya (ekuitas).

Pengukuran rasio solvabiliteitau rasio leverage, dilakukan melalui dua pendekatan, antar lain :

1. Mengukur rasio-rasio neraca dan sejauh mana pinjaman dipergunakan buat permodalan;

2. Melalui pendekatan rasio-rasio untung rugi.

\section{B. Tujuan dan Manfaat Rasio Solvabilitas}

Untuk memilih menggunakan modal sendiri atau modal pinjaman haruslah menggunakan beberapa perhitungan. Seperti diketahui bahwa penggunaan modal sendiri atau dari modal pinjaman akan memberikan dampak tertentu bagi perusahaan. Pihak manajemen harus pandai mengatur rasio kedua modal tersebut. Pengaturan rasio yang baik akan memberikan banyak manfaat bagi perusahaan guna menghadapi segala kemungkinan yang akan terjadi. Namun semua kebijakan ini tergantung dari tujuan perusahaan secara keseluruhan.

Berikut adalah beberapa tujuan perusahaan dengan menggunakan rasio solvabilitas yakni :

1. untuk mengetahui posisi perusahaan terhadap kewajiban kepada pihak lainnya (kreditor);

2. untuk menilai kemampuan perusahaan dalam memenuhi kewajiban yang bersifat tetap (seperti angsuran pinjaman termasuk bunga); 
3. untuk menilai keseimbangan antara nilai aktiva khususnya . aktiva tetap dengan modal;

4. untuk menilai seberapa besar aktiva perusahaan dibiayai oleh utang;

5. untuk menilai seberapa besar pengaruhutangperusahaan terhadap pengelolaan aktiva;

6. untuk menilai atau mengukur berapa bagian darisetiap rupiah modal sendiri yang dijadikan jaminan utang jangka panjang; .

7. untuk menilai berapa dana pinjaman yang segera akan ditagih, terdapat sekian kalinya modal sendiri yang dimiliki; dan tujuan lainnya.

Intinya adalah dengan analisis rasio solvabilitas, perusahaan akan mengetahui beberapa hal berkaitan dengan penggunaan modal sendiri dan modal pinjaman serta mengetahui rasio kemampuan perusahaan untuk memenuhi kewajibannya. Setelah diketahui, manajer keuangan dapat mengambil kebijakan yang dianggap perlu guna menyeimbangkan penggunaan modal. Akhirnya,dari rasio ini kinerja manajemen selama ini akan terlihat apakah sesuai tujuan perusahaan atau tidak.

\section{Jenis-jenis Rasio Solvabilitas}

Biasanya penggunaan rasio solvabilitas leverage disesuaikan dengan tujuan perusahaan. Artinya perusahaan dapat menggunakan rasio leverage secara keseluruhan atau sebagian dari masing-masing jenis rasio solvabiliteitang ada. Penggunaan rasio secara keseluruhan, artinya seluruh jenis rasio yang dimiliki perusahaan, sedangkan sebagian artinya perusahaan hanya menggunakan beberapa jenis rasio yang dianggap perlu untuk diketahui.

Dalam praktiknya, terdapat beberapa jenis rasio solvabilite yang sering digunakan perusahaan. Adapun jenis-jenis rasio yang ada dalam rasio solvabilitas antara lain : 
1. debt to asset ratio (debt ratio)

2. debt to equity ratio

3. long term debt to equity ratio

4. tangible assets debt coverage

5. current liabilities to net worth

6. times interest earned.

7. Fixed charge coverage

Untuk memberikan contoh aplikasi rasio diatas berikut ini diberikan contoh neraca PT Yumiko Maharani, Tbk.

\section{Debt to Asset Ratio (Debt Ratio)}

Debt to Ratio menurut Kasmir (2012), adalah rasio utang yang digunakan untuk mengukur rasio total utang terhadap total aset. Sebelumnya, Kasmir (2010) juga mengatakan bahwa kuota yang tinggi membuat sulit untuk mendapatkan kredit tambahan, karena peningkatan utang dan penggalangan dana dapat membuat aset tidak mungkin menutupi utang. Demikian pula, semakin kecil perusahaan dibiayai dengan hutang, semakin rendah tingkat bunga.

Debt Ratio merupakan rasio utang yang digunakan untuk mengukur perbandingan antara total utang dengan total aktiva. Dengan kata lain, seberapa besar aktiva perusahaan di biayai oleh utang atau seberapa besar utang perusahaan berpengaruh terhadap pengelolaan aktiva.

Dari hasil pengukuran, apabila rasionya tinggi, artinya pendanaan dengan utang semakin banyak, maka semakin sulit bagi perusahaan untuk memperoleh tambahan pinjaman karena dikhawatirkan perusahaan tidak mampu menutupi piutangnya dengan aktiva yang dimilikinya. Demikian pula apabila rasionya rendah, semakin kecil perusahaan dibiayai dengan utang. Standar pengukuran untuk menilai baik tidaknya rasio perusahaan, digunakan rasio rata-rata industri yang sejenis. 
Misal hasil analisis pada tahun 2014 debt rasio bank syariah mandiri sebesar 2,53. Kemudian pada tahun 2015 dan 2016, rasionya menurun hingga sebesar 2,46. Utang dimaksudkan disini untuk membantu perbankan dalam memperlancar pelaksanaan opersionalnya, karena secara harfiah laverage diartikan sebagai pengungkit, dikaitkan dengan keuangan laverage bisa digunakan untuk meningkatkan tingkat keuntungan yang diharpakan. (Mamduh M. Hanafi, 2013) Jika rata-rata industri debt ratio adalah 35\% maka keadaan bank syariah mandiri dapat dikatakan baik atau sehat karena rasionya di atas rata-rata industri sehingga mempermudah perusahaan untuk memperoleh pinjaman. Perusahaan yang tumbuh mempunyai leverage yang lebih kecil daripada perusahaan yang tidak tumbuh dengan pertimbangan untuk mengurangi resiko usahanya, apabila terjadi kegagalan sehingga tidak mampu membayar bunga hutang. (Yetti \& Suryanto, 2002)

Rumusan untuk mencari debt ratio dapat digunakan sebagai berikut :

$$
\text { Debt to asset ratio }=\frac{\text { Total } \text { Debt }}{\text { Total asset }}
$$

Contoh :

\begin{tabular}{|c|c|c|}
\hline Komponen Laporan Keuangan & $\mathbf{2 0 0 5}$ & $\mathbf{2 0 0 6}$ \\
\hline Total aktiva ( total asset ) & 4.200 & 4.000 \\
\hline Total utang ( total debt ) & 2.050 & 1.900 \\
\hline
\end{tabular}

Untuk tahun 2005 :

Debt to asset ratio $=\frac{R p \cdot 2.050}{R p \cdot 4.200}=0,488$ dibulatkan (49\%) 
Rasio ini menunjukkan bahwa $49 \%$ pendanaan perusahaan dibiayai dengan utang untuk tahun 2005. Artinya, bahwa setiap Rp100,00 pendanaan perusahaan, Rp49,00 dibiayai dengan utang dan Rp41,00 disediakan oleh pemegang saham.

Untuk tahun 2006 :

Debt to asset ratio $=\frac{R p \cdot 1.900}{R p \cdot 4.000}=0,475$ dibulatkan (48\%)

Rasio ini menunjukkan bahwa sekitar $48 \%$ pendanaan perusahaan dibiayai dengan utang untuk tahun 2005. Artinya, setiap Rp100,00 pendanaan perusahaan, Rp48,00 dibiayai dengan utang dan Rp52,00 disediakan oleh pemegang saham.

Jika rata-rata industri $35 \%$, debt to asset ratio perusahaan masih di bawah rata-rata industri sehingga akan sulit bagi perusahaan untuk memperoleh pinjaman. Kondisi tersebut juga menunjukkan perusahaan dibiayai hampir separuhnya utang. Jika perusahaan bermaksud menambah utang, perusahaan perlu menambah dulu ekuitasnya. Secara teoretis, apabila perusahaan dilikuidasi masih mampu menutupi utangnya dengan aktiva yang dimiliki.

\section{Debt to Equity Ratio}

Debt to Equity Ratio/ Ratio Laverage adalah ukuran keuangan yang dapat digunakan oleh pemilik modal untuk mengukur kemampuannya dalam memenuhi semua kewajibannya, baik hutang jangka pendeknya maupun hutang jangka ataupun hutang jangka panjang. Rasio ini dapat digunakan untuk mengetahui setiap rupiah modal sendiri yang dijadikan untuk jaminan utang. 
Kasmir (2010), menyatakan bahwa Debt to equity ratio adalah rasio yang digunakan untuk menilai utang dan ekuitas. Rasio ini dihitung dengan membandingkan seluruh utang, termasuk utang jangka pendek, terhadap total modal. Lain halnya dengan pendapat, Fahmi (2014) yang menyatakan bahwa rasio solvabilitas merupakan indikator bagaimana suatu perusahaan mengelola utangnya dan melunasinya untuk memperoleh keuntungan. Sedangkan menurut Andreani, (2013) Debt to equity ratio adalah suatu kondisi yang menunjukkan rasio utang terhadap modal perusahaan, atau kemampuan sebuah perusahaan untuk menjalankan bisnis dengan modal ekuitas. Dengan kata lain, semakin banyak modal yang digunakan untuk menjalankan kegiatan operasional sebuah perusahaan, maka akan semakin kecil kemungkinan untuk meminjam untuk meminimalkan kewajiban perusahaan untuk membayar bunga.

Dalam menggunakan Debt to Equity Ratio terdapat beberapa keuntungan yang diperoleh, antara lain :

1. Perhitungan dan pengukuran jumlah keuntungan

2. Tinjauan berkala terhadap laba

3. Equitas dapat digunakan untuk mengevaluasi laba bersih setelah pajak

4. Mengukur tingkat produktivitas usaha dari seluruh sumber daya yang digunakan (baik hutang maupun modal)

Bagi bank (kreditor), semakin besar rasio ini, akan semakin tidak menguntungkan karena akan semakin besarrisikoyang ditanggung atas kegagalan yang mungkin terjadi di perusahaan. Namun, bagi perusahaan justru semakin besar rasio akan semakin baik. Sebaliknya dengan rasio yang rendah, semakin tinggi tingkat pendanaan yang disediakan pemilik dan semakin besar batas pengamanan bagi peminjam jika terjadi kerugian atau penyusutan terhadap nilai aktiva. Rasio ini juga memberikan petunjuk umum tentang kelayakan dan risiko keuangan perusahaan. 
Misalnya utang harus bisa di kelola dengan baik agar tidak menjadi beban yang nantinya akan menyulitkan sendiri Bank Syariah Mandiri syariah. Jumlah Utang yang sudah sangat besar akan mengurangi fleksibilitas dalam memperoleh pinjaman. Hal ini dimaksudkan bahwa perusahaan mempunyai tingkat kelenturan tertentu dalam menghadapi situasi tidak terduga dalam pendanaanya. (Toto Prihadi, 2013). Hasil dari rasio ini menunjukkan bahwa kreditur menyediakan Rp. 340 pada tahun 2014 untuk setiap Rp. 100 yang disedikan pemegang saham. Untuk tahun 2015 yaitu Rp. 308, dan pada tahun berikutnya yaitu tahun 2016 rasionya sebesar Rp. 303. Ini menunjukkan lebih baik dari tahun sebelumnya atau ada peningkatan dalam penyediaan dana.

Debt to equity ratio untuk setiap perusahaan tentu berbeda-beda, tergantung karakteristik bisnis dan keberagaman arus kasnya. Perusahaan dengan arus kas yang stabil biasanya memiliki rasio yang lebih tinggi dari rasio kas yang kurang stabil.

Rumus untuk mencari debt to equity ratio dapat digunakan perbandingan antara total utang dengan total ekuitas sebagai berikut.

Debt to equity ratio $=\frac{\text { Total utang }(\text { Debt })}{\text { Equitas }(\text { Equity })}$

Contoh :

\begin{tabular}{|c|c|c|}
\hline Komponen Laporan Keuangan & $\mathbf{2 0 0 5}$ & $\mathbf{2 0 0 6}$ \\
\hline Total utang(Debt) & 2.050 & 1.900 \\
\hline Total Ekuitas (Equity) & 2.250 & 2.100 \\
\hline
\end{tabular}

Untuk tahun 2005 :

Debt to equity ratio $=\frac{2.050}{2.250}=0,911 \%(91 \%)$ 
Untuk tahun 2006 :

Debt to equity ratio $=\frac{1.900}{2.100}=0,904 \%(91 \%)$

Rasio ini . menunjukkan bahwa kreditor menyediakan Rp91,00 tahun 2005 untuk setiap Rp100,00 yang disediakan pemegang saham. Atau perusahaan dibiayai oleh utang sebanyak 91\%. Demikian pula untuk tahun 2006 tidak jauh berbeda dengan tahun 2005, yaitu sebesar 90,4\% mendekati $91 \%$

Jika rasio rata-rata industri untuk debt to equity ratio sebesar $80 \%$, perusahaan masih dianggap kurang baik karena berada di atas rata-rata industri. Demikian pula untuk tahun 2006 kurang baik dan tidak jauh berbeda dengan tahun 2005.

\section{Long Term Debt to Equity Ratio (LTDtER)}

LTDtER merupakan rasio antara utang jangka panjang dengan modal sendiri. Tujuannya adalah untuk mengukur berapa bagian dari setiap rupiah modal sendiri yang dijadikan jaminan utang jangka panjang dengan cara membandingkan antara utang jangka panjang dengan modal sendiri yang disediakan oleh perusahaan.

Rumusan untuk mencari long term debt to equity ratio adalah dengan menggunakan perbandingan antara utang jangka panjang dengan modal sendiri, yaitu :

LTDtER $=\frac{\text { Long term debt }}{\text { Equity }}$ 
Contoh :

\begin{tabular}{|c|c|c|}
\hline Komponen Laporan Keuangan & $\mathbf{2 0 0 5}$ & $\mathbf{2 0 0 6}$ \\
\hline Total utang jangka panjang & 1.300 & 1.150 \\
\hline Total Ekuitas & 2.250 & 2.100 \\
\hline
\end{tabular}

Untuk tahun 2005 :

$\operatorname{LTDtER}=\frac{1.300}{2.250}=0,577 \%(58 \%)$

Untuk tahun 2006 :

$\operatorname{LTDtER}=\frac{1.150}{2.100}=0,547 \%(55 \%)$

\section{Times Interest Earned}

Berdasarkan J. Fred Weston Times Interest Earned ialah rasio untuk mencari jumlah kali perolehan bunga. Rasio ini diartikan oleh James C.Van Horne juga menjadi kemampuan perusahaan untuk membayar biaya bunga, sama seperti coverage ratio.

Jumlah kali perolehan bunga atau times interest earned ialah rasio untuk mengukur sejauh mana pendapatan bisa menurun tanpa membuat perusahaan merasa malu sebab tidak mampu membayar biaya bunga tahunannya. Bila perusahaan tidak bisa membayar bunga, dalam jangka panjang. Menghilangkan kepercayaan dari para kreditor. Bahkan ketidakmampuan menutup biaya tidak 
menutup kemungkinan akan mengakibatkan adanya tuntutan aturan asal kreditor. Lebih berasal itu, kemungkinan perusahaan menuju ke arah pailit semakin besar.

Secara umum semakin tinggi rasio, semakin besar kemungkinan perusahaan dapat membayar bunga pinjaman serta bisa sebagai berukuran untuk memperoleh tambahan pinjaman baru asal kreditor. Demikian pula kebalikannya apabila rasionya rendah, semakin rendah pula kemampuan perusahaan untuk membayar bunga serta biaya lainnya.

Buat mengukur rasio ini, dipergunakan perbandingan antara laba sebelum bunga serta pajak dibandingkan dengan biaya bunga yang dikeluarkan. Dengan demikian, kemampuan perusahaan buat membayar bunga pinjaman tidak dipengaruhi oleh pajak.

Rumus untuk mencari times interest earned dapat digunakan dengan dua cara sebagai berikut :

Times Interest Earned $=\frac{E B I T}{\text { Biaya bunga (Interest })}$

Atau :

Times Interest Earned $=\frac{\text { EBIT }+ \text { Biaya bunga }}{\text { Biaya bunga }(\text { Interest })}$

Contoh :

\begin{tabular}{|c|c|c|}
\hline Komponen Laporan Keuangan & $\mathbf{2 0 0 5}$ & $\mathbf{2 0 0 6}$ \\
\hline Total utang jangka panjang & 1.800 & 1.300 \\
\hline Total Ekuitas & 180 & 170 \\
\hline
\end{tabular}


Untuk tahun 2005 :

Times Interest Earned $=\frac{R p \cdot 1.800}{R p \cdot 180}=10$ Kali

Untuk tahun 2006 :

Times Interest Earned $=\frac{R p \cdot 1 \cdot 300}{R p \cdot 170}=7,6$ Kali

Times interest earned tahun 2005 adalah 10 kali atau dengan kata lain, biaya bunga dapat ditutup 10 kali dari laba sebelum bunga dan pajak. Kemudian, untuk tahun 2006 adalah 7,6 kali atau dengan kata lain biaya bunga dapat ditutup 7,6 kali laba sebelum bunga dan pajak.

Apabila rata-rata industri untuk usaha yang sejenis10 kali, rasio. untuk tahun 2005 baik. Akan tetapi, untuk tahun 2006, dinilai kurang baik karena masih di bawah rata-rata industri 10 kali. Hal ini akan menyulitkan perusahaan untuk memperoleh tambahan pinjaman di kemudian hari.

\section{Charge Coverage (FCC)}

Fixed charge coverage atau lingkup biaya tetap artinya rasio yang menyerupai Times Interest Earned Ratio. Hanya saja. Perbedaannya artinya rasio ini dilakukan bila perusahaan memperoleh utang jangka panjang atau menyewa aktiva sesuai kontrak sewa (lease contract). Biaya permanen artinya biaya bunga ditambah kewajiban sewa tahunan atau jangka panjang. 
Rumus untuk mencari fixed charge coverage (FCC)adalah sebagai berikut :

Fixed charge coverage $=\frac{\text { EBIT }+ \text { Biaya bunga }+ \text { Kewajiban sewa } / \text { lease }}{\text { Biaya bunga }+ \text { Kewajiban sewa } / \text { lease }}$

Contoh :

\begin{tabular}{|l|c|c|}
\hline Komponen Laporan Keuangan & $\mathbf{2 0 0 5}$ & $\mathbf{2 0 0 6}$ \\
\hline Earning Before Tax (EBIT) & 1.620 & 1.130 \\
\hline Biaya Bunga & 180 & 170 \\
\hline Kewajiban sewa/lease & 40 & 30 \\
\hline
\end{tabular}

Untuk tahun 2005 :

FCC $=\frac{1.650+180+40}{180+80}=8,5$ Kali

Untuk tahun 2006 :

FCC $=\frac{2.130+170+30}{170+30}=11,65$ Kali $(12$ Kali $)$

Seandainya rata-rata industri untuk fixed charge coverage adalah 10 kali, untuk tahun 2005, hanya 8,5 kali dan ini dinilaikurang baik karena masih di bawah rata-rata industri dan tentu menyulitkan perusahaan untuk memperoleh pinjaman. Sementara . itu, untuk tahun 2006, dengan rasio 12 kali dianggap cukup baik karena berada di atas rata-rata industri sehingga memudahkan perusahaan untuk memperoleh pinjaman. 


\section{Hasil Pengukuran}

Dari pengukuran rasio di atas dapat kita lihat kondisi dan posisi perusahaan seperti yang terlihat dalam tabel berikut ini.

\begin{tabular}{|c|l|c|c|c|}
\hline No. & \multicolumn{1}{|c|}{ Jenis Rasio } & $\mathbf{2 0 0 5}$ & $\mathbf{2 0 0 6}$ & Standar Industri \\
\hline 1. & Debt to asset ratio & $49 \%$ & $48 \%$ & $35 \%$ \\
\hline 2. & Debt to equity ratio & $91 \%$ & $90 \%$ & $90 \%$ \\
\hline 3. & Long Term Debt to & $58 \%$ & $55 \%$ & 10 Kali \\
\hline 4. & Equity Ratio (LTDtER) & & & 10 Kali \\
\hline 5. & Times Interest Earned & 10 Kali & 7,6 Kali & 10 Kali \\
\hline 6. & Fixed charge coverage & 8,5 Kali & 12 Kali & \\
\hline
\end{tabular}

Debt to Asset Ratio tahun 2005 sebanyak 49\% artinya dari aktiva perusahaan didanai utang (modal pinjaman) sebesar 49\% dan ini juga berarti sebanyak 41\% dibiayai dengan modal dari pemegang saham. Kemudian tahun 2006 sebanyak $48 \%$ dari aktiva perusahaan didanai utang (modal pinjaman) dan sebanyak $42 \%$ dibiayai dengan modal dari pemegang saham. Jika dibandingkan dengan standar rata-rata industri 35\%, kondisi perusahaan untuk. tahun 2005 dan 2006 dinilai kurang baik. Artinya perusahaan dibiayai dengan utang melebihi ratarata industri.

Debt to equity ratio menunjukkan bahwa kreditor menyediakan Rp91,00 pada tahun 2005 untuk setiap Rp100,00 yang disediakan pemegang saham. Perusahaan dibiayai oleh utang sebanyak 91\%. Demikian pula untuk tahun 2006 tidak jauh berbeda dengan tahun 2005, yaitu sebesar 90,4\% mendekati $90 \%$.

Jika rasio rata-rata industri untuk debt to equity ratio sebesar $80 \%$, perusahaan masih dianggap kurang baik karena berada di atas rata-rata industri. 
Demikian pula untuk tahun 2006 dinilai kurang baik dan tidak jauh berbeda dengan tahun 2005.

Times interest earned pada tahun 2005 adalah 10 kali atau dengan kata lain, biaya bunga dapat ditutup 10 kali laba sebelum bunga dan pajak. Kemudian, untuk tahun 2006, times interest earned adalah 7,6 kali atau dengan kata lain, biaya bunga dapat .. ditutup 7,6 kali laba sebelum bunga dan pajak.

Apabilarata-rata industri untuk usaha yang sejenis 10 kali, rasiountuktahun 2005 baik. Akan tetapi, untuk tahun 2006 dinilaikurangbaik karena masih di bawah rata-rata industri $10 \mathrm{kali}$. Hal ini akan menyulitkan perusahaan untuk memperoleh pinjamandikemudian hari.

Seandainya rata-rata industri untuk fixed charge coverage adalah 10 kali, untuk tahun 2005 hanya 8,5 kali dan ini dinilai kurang baik karena masih di bawah rata-rata industri dan tentu menyulitkan perusahaan untuk memperoleh tambahan pinjaman baru. Sementara itu, tahun 2006 dengan rasio 12 kali dianggap cukup baik karena berada di atas rata-rata industri sehingga memudahkan perusahaan untuk memperoleh pinjaman. 


\section{BAB III}

\section{PENUTUP}

\section{Kesimpulan}

Rasio solvabilitas atau leverage ratio merupakan rasio yang digunakan untuk mengukur sejauh mana aktiva perusahaan dibiayai dengan utang. Dalam arti luas dikatakan bahwa rasio solvabiliteitunakan untuk mengukur kemampuan perusahaan untuk membayar seluruh kewajibannya, baik jangka pendek maupun jangka panjang apabila perusahaan dibubarkan.

Tujuan dan manfaat rasio solvabilitas adalah :

1. untuk menilai dan mengetahui kemampuan posisi perusahaan terhadap kewajiban kepada pihak lainnya;

2. untuk menilai dan mengetahui kemampuan perusahaan memenuhi kewajiban yang bersifat tetap;

3. untuk menilai dan mengetahui keseimbangan antara nilai aktiva khususnya aktiva tetap dengan modal;

4. untuk menilai dan mengetahui seberapa besar aktiva perusahaan dibiayai oleh utang;

5. untuk menilai dan mengetahui seberapa besar utang perusahaan berpengaruh terhadap pengelolaan aktiva;

6. untuk menilai dan mengetahui atau mengukur berapa bagian dari setiap rupiah modal sendiri yang dijadikan jaminan utang jangka panjang;

7. untuk menilai dan mengetahui berapa dana pinjamanyang segera akan ditagih ada terdapat sekian kalinya modal sendiri.

Jenis-jenis rasio solvabilitas : debt to asset ratio (debt ratio), debt to equity ratio, long term debt to equity ratio, times interest earned dan fixed charge coverage. Debt to asset ratio (debt ratio) merupakan rasio yang digunakan untuk mengukur 
perbandingan antara total utang dengan total aktiva. Dengan kata lain, seberapa besar aktiva perusahaan dibiayai oleh utang atau seberapa besar utang perusahaan berpengaruh terhadap pengelolaan aktiva. Debt to equity ratio merupakan rasio yang digunakan untuk mengetahui perbandingan antara total utang dengan modal sendiri. Rasio ini berguna untuk mengetahui seberapa besar aktiva perusahaan dibiayai dari utang. Long term debt to equity ratio merupakan rasio antara utang jangka panjang dengan modal sendiri. Tujuannya adalah untuk mengukur berapa bagian dari setiap rupiah modal sendiri yang dijadikan jaminan utang jangka panjang. Times interest earned merupakan rasio untuk mencari jumlah kali perolehan bunga. Rasio ini diartikan juga kemampuan perusahaan untuk membayar biaya bunga, sama seperti coverage ratio. Fixed charge coverage atau lingkup biaya tetap merupakan rasio yang digunakan menyerupai rasio times interest earned. Hanya saja dalam rasio ini dilakukan apabila perusahaan memperoleh utang jangka panjang atau menyewa aktiva berdasarkan kontrak sewa (lease contract). 


\section{DAFTAR PUSTAKA}

Kasmir. (2008). Analisis Laporan Keuangan. Depok: Rajawali Pers.

Mawarsih, S., Ramadhani, F., Irawati, L., \& Fadillah, N. (2020). Total Asset Turn Over, Debt to Asset Ratio, dan Debt to Equity Ratio Terhadap Return On Asset Pada perusahaan Sub Sektor Asuransi. Jurnal Ekonomi, Keuangan dan Perbankan Syariah, 34-35.

Muhlis, M. (2021). METODE RASIO SEBAGAI TOOL'S KINERJA KEUANGAN PT BANK SYARIAH MANDIRI. Ar-Ribh: Jurnal Ekonomi Islam, 4(1).

Sudirman, S., Kamaruddin, K., \& Possumah, B. T. (2020). The Influence of Net Profit Margin, Debt to Equity Ratio, Return on Equity, and Earning per Share on the Share Prices of Consumer Goods Industry Companies in Indonesia. International Journal of Advanced Science and Technology, 29(7), 13428-13440. 